\title{
M
}

\section{Down Syndrome Legislation in the U.S. and Italy: A Comparison}

FRANCESCA GOTTARDI, ESQ.

Ph.D. Candidate

University of Cincinnati, School of Public and International Affairs

gottarfa@mail.uc.edu

\section{ABSTRACT}

How do we guarantee dignity and quality of life to individuals with Down syndrome? If a family cannot commit to granting a dignified life, or if there are other health concerns at issue, how do we balance the right of the mother, parents, and unborn child? This article offers a comparative perspective of the disability legal framework in the U.S. and Italy, focusing on Down syndrome. In Italy, healthcare is public and universal, while in the United States healthcare is mostly privatized. In this context, in the U.S. people with mental and physical disabilities are particularly vulnerable due to the high costs of healthcare, stigma, and the need for additional advocacy. This work compares the Americans with Disabilities Act (ADA) in the U.S., the Legge 104/1992 in Italy, and the Convention on the Rights of Persons with Disabilities (CRPD) internationally. Numerous policy considerations impact the lives of individuals with Down syndrome, from conception to delivery, and from early childhood throughout development. There is a controversial legal

DOI: $10.54103 /$ milanlawreview/17393 
debate concerning abortion if the fetus has an identified genetic abnormality. Additionally, once individuals with Down syndrome are born, how does the legal framework support these children and their families? Law and policy regarding access to care make a big difference in the quality of life of people with Down syndrome. At first glance, the standpoint of protecting and supporting a child with Down syndrome, and that of protecting the parents' right to terminate a pregnancy, might seem antithetical. However, they are, in fact, part of the same (difficult) conversation. By adopting a person-centered approach, paired with a relationship-centered care approach, we can pursue the holistic and humanistic ideals that our society aspires to achieve.

Keywords: International Law; International Human Rights; Disability Law; Comparative Law; Italian Law; American Law; Down Syndrome

This paper has been subjected to double-blind peer review 


\section{Down Syndrome Legislation in the U.S. and Italy: A Comparison}

SUMMARY: 1. Introduction - 1.1. Research Methods and Design - 2. Law and Policies Concerning Down Syndrome Across the Lifespan - 2.1. Defining Down Syndrome - 2.2. The Convention on the Rights of Persons with Disabilities (CRPD) and the Role of the United Nations - 2.2.1. Convention on the Rights of Persons with Disabilities: Steps Ahead - 2.3. The Americans with Disabilities Act (ADA) and Down Syndrome - 2.3.1. The Americans with Disabilities Act: Steps Ahead 2.4. Disability Law in Italy: The Legge 104/1992 - 3. Conception to Delivery and Pregnancy Termination: A Contested Legal Issue -3.1. Reproductive Rights in The United States - 3.1.1. Ohio: The Ohio House Bill 214 - 3.1.2. Texas: Senate Bill 8 3.1.3. Mississippi: The Gestational Age Act - 3.2. Italy: Law n.194/1978 - 4. Early Childhood and Development - 4.1. The United States and Italy: Cost and Access to Care - 5. Conclusive Remarks: Proposals Going Forward.

\section{Introduction}

This work stems from my experience as a law practitioner in two different countries, the United States and Italy, with two different legal systems, the common law and the civil law system. Coming from the European reality, where healthcare is public and accessible for everyone, I struggled to understand the U.S. system, especially how a significant part of the population is de facto excluded due to high costs. In this context, people with mental and physical disabilities are particularly vulnerable, not only because of the costs involved, but also due to the presence of stigma and need for additional advocacy.

This article offers a comparative perspective of the disability law framework in the United States and Italy, focusing on Down syndrome. My interest in this topic results from my experience spending four summers working with two twins with Down syndrome and the bond I developed with them. I wish for them to be treated with the dignity inherent to human beings by professionals equipped to provide for their best interests.

This work also stems from my interest in looking at how parents of children who have Down syndrome cope and their thoughts and perspectives about access to abortion if the fetus has Down syndrome. At first glance, the standpoint of protecting a child with Down syndrome, and that of protecting the parents' right to pursue abortion, might seem antithetical. However, I think they are, in fact, part 
of the same (difficult) conversation. How do we guarantee dignity and quality of life to individuals with Down syndrome? If families cannot commit to granting such life, or if there are other health concerns at issue, how do we balance the right of the mother, parents, and unborn child? This article addresses these questions by examining the current policy and legal frameworks in the U.S. and in Italy.

\subsection{Research Methods and Design}

This paper addresses relevant legal and policy issues impacting a person with Down syndrome, from conception through childhood and development. I examine the legal and policy framework in Europe and specifically in Italy, versus in the United States and particularly in Ohio (with mentions to Texas and Mississippi). These are localities that well represent the country or Union in which they are embedded.

I start by giving an overview of the international and domestic legal framework pertaining to Down syndrome. I then move on to address the conception-to-delivery timeframe, which presents a contested legal issue, specifically regarding termination of pregnancy when the fetus has Down syndrome. Then, I discuss early childhood and development, focusing on how the U.S. and Italy assist families with children with Down syndrome, particularly on access to care. Finally, in my conclusive remarks, I highlight the main challenges ahead and suggest areas for future research.

As for the methods, I rely on primary sources, such as policy and legislation, and secondary sources, such as relevant scholarly articles. With over 6,000 new births involving a child with Down syndrome a year in the United States alone, this is a common syndrome and disability. Down syndrome has been thoroughly studied and discussed in legal and public policy arenas worldwide, allowing for a good availability of primary and secondary sources to work with. With this paper, I intend to offer a comparative perspective at the intersection of law and policy where - contrary to my expectations - there is a notable lack of literature available. In small part, I draw from my personal experience of assisting two children with Down syndrome. Finally, a brief note on language. In this work, I use the expression Down syndrome instead of Down's syndrome because it is the National Down syndrome Society (NDSS) preferred language. ${ }^{1}$

${ }^{1}$ NDSS Preferred Language Guide, NATIONAL DOWN SYNDROME SOCIETY, 'NDSS-PreferredLanguage-Guide-2020-2.Pdf' <https://www.ndss.org/wp-content/uploads/2020/11/NDSSPreferred-Language-Guide-2020-2.pdf $>$ accessed 1 January 2022. 


\section{Law and Policies Concerning Down Syndrome Across the Life Span}

Numerous laws and policy considerations impact the lives of individuals with Down syndrome across their life span. This work compares and contrasts the Americans with Disabilities Act (ADA) in the U.S., the Legge 104/1992 in Italy, and the Convention on the Rights of Persons with Disabilities (CRPD) internationally, starting from the very definition of Down syndrome.

\subsection{Defining Down Syndrome}

Down syndrome is described by the Mayo Clinic as a genetic condition involving chromosome 21 which causes developmental and intellectual delays. ${ }^{2}$ There is significant heterogeneity in how this syndrome impacts an individual. Common features include impairments in cognitive ability and physical growth, mild to moderate developmental disabilities, and a higher risk for heart defects as well as certain problems with the gastrointestinal system. ${ }^{3}$ Protruding tongue, poor muscle tone, and excessive flexibility are often present. ${ }^{4}$ Further, individuals with Down syndrome may develop various secondary complications, which tend to worsen with age, such as eye and vision problems, immune disorders, sleep apnea, obesity, spinal issues, leukemia, and early-onset dementia. ${ }^{5}$

Down syndrome is the most common genetic chromosomal disorder. ${ }^{6}$ In the United States, there are 3.8 million births a year, and over 6,000 of these newborns have Down syndrome. ${ }^{7}$ This means that Down syndrome occurs in about 1 in every 633 babies. $^{8}$ In the European Union (E.U.), there are 5.2 million births a year, 104,000 of those (2.5 percent) carry congenital anomalies, and 8,320 of those congenital anomalies (8 percent) are Down syndrome. ${ }^{9}$ This means that

\footnotetext{
2 'Down Syndrome - Symptoms and Causes' (Mayo Clinic) $<$ https://www.mayoclinic.org/diseases-conditions/down-syndrome/symptomscauses/syc-20355977> accessed 1 January 2022.

${ }^{3}$ CDC, 'Data and Statistics on Down Syndrome I CDC' (Centers for Disease Control and Prevention, 4 December 2019)

$<$ https://www.cdc.gov/ncbddd/birthdefects/downsyndrome/data.html> accessed 1 January 2022.

4 ibid.

5 'Down Syndrome - Symptoms and Causes' (n 2).

${ }^{6}$ ibid.

${ }^{7} \mathrm{CDC}$ (n 3).

8 ibid.

9 Bruno Cattaneo, 'Down Syndrome in Europe - Has the Disorder Epidemiology Changed over the Last Quarter-Century?' (EU Science Hub - European Commission, 21 March 2019) <https://ec.europa.eu/jrc/en/news/down-syndrome-europe-has-disorderepidemiology-changed-over-last-quarter-century> accessed 1 January 2022.
} 
Down syndrome occurs in approximately 1 in every 625 newborns in Europe, which is comparable to that of the U.S. (1 in 633).

\subsection{The Convention on the Rights of Persons with Disabilities (CRPD) and the Role of the United Nations}

The Convention on the Rights of Persons with Disabilities (CRPD) and its Optional Protocol are the first comprehensive human rights treaty to advance the rights and dignity of people with disabilities worldwide. ${ }^{10}$ They were adopted on 13 December 2006 at the United Nations Headquarters in New York and entered into force on 3 May 2008. ${ }^{11}$ The CRPD was subsequently opened for signature on 30 March 2007. There were 82 signatories to the Convention, which is the highest number of signatories to a U.N. Convention on its opening day. ${ }^{12}$ This speaks to how deeply the need for a convention aimed at protecting the rights of people with disabilities was felt worldwide. The streak of disability law-oriented legislation started in the nineties by addressing the need for protecting people with mental illness. In 1991, the United Nations General Assembly adopted the 46/119 resolution, titled "The Protection of Persons with Mental Illness and the Improvement of Mental Health Care."13

As of today, 164 states signed the CRPD, and 182 ratified it. ${ }^{14}$ The reason why the number of states that ratified the Convention is larger than those that signed is that some states ratified the CRPD directly, without taking part in the signing stage. However, for some countries, the opposite is true; they have signed, but not ratified, the Convention. ${ }^{15}$ The United States signed the Convention on July 30, 2009. However, the U.S. failed to ratify it by five votes in December 2012, and

10 'Convention on the Rights of Persons with Disabilities (CRPD) I United Nations Enable' <https://www.un.org/development/desa/disabilities/convention-on-the-rights-ofpersons-with-disabilities.html> accessed 1 January 2022.

11 ibid.

12 ibid.

${ }_{13}$ 'Principles for the Protection of Persons with Mental Illness and the Improvement of Mental Health Care' <http://digitallibrary.un.org/record/162032> accessed 1 January 2022. ${ }^{14}$ Multilateral Treaties Deposited with Secretary-General, 'United Nations Treaty Collection' $<$ https://treaties.un.org/pages/ViewDetails.aspx?src=TREATY\&mtdsg_no=IV15\&chapter=4> accessed 1 January 2022.

15 ibid. 
to date, no ratification has taken place. ${ }^{16}$ Italy signed the Convention on March 30, 2007 and ratified it on May 15, 2009. ${ }^{17}$

The CRPD promotes a cultural shift from viewing people with disabilities as passive receivers of medical treatments and social protection to active and autonomous members of society with rights and with the capability of claiming them. ${ }^{18}$ It also "set out a code of implementation" so that nations that join the Convention commit to developing policies and legislation to promote the inherent dignity of people with disabilities--such as those with Down syndrome--and to abolish those that are discriminatory (art. 4). ${ }^{19}$

Notably, in 2011, the U.N. specifically encouraged further inclusion of people with Down syndrome in social, economic, and political life by declaring March 21 as the World Down syndrome Day (WDSD). The date $\left(21^{\text {st }}\right.$ day of the $3^{\text {rd }}$ month of the year) was chosen to signify the uniqueness of the triplication (trisomy) of the 21st chromosome, which causes Down syndrome. ${ }^{20}$ Each year, the U.N. hosts an international convention, the WDSD Conference, at the U.N. headquarters in New York. ${ }^{21}$ Instituting the WDSD day was an important step in fostering awareness in the international community on Down syndrome and promoting further discussion on the steps we can take to build an inclusive society.22 The U.N. action had a snowball effect. Other institutions and local governments followed the U.N.'s lead to declare Down syndrome Awareness initiatives and events around WDSD each year. ${ }^{23}$

\subsubsection{Convention on the Rights of Persons with Disabilities: Steps Ahead}

With the Convention on the Rights of Persons with Disabilities (CRPD), the U.N. took a remarkable stance towards the intended social development direction that the U.N. promotes. The CRPD provided a tool for countries to use to stand up

16 ibid.; 'Where the United States Stands on 10 International Human Rights Treaties' (The Leadership Conference Education Fund) <https://civilrights.org/edfund/resource/where-theunited-states-stands-on-10-international-human-rights-treaties/> accessed 1 January 2022. 17 'United Nations Treaty Collection' (n 14).

18 'Convention on the Rights of Persons with Disabilities (CRPD) I United Nations Enable' (n 10).

19 'The Convention in Brief I United Nations Enable'

$<$ https://www.un.org/development/desa/disabilities/convention-on-the-rights-of-personswith-disabilities/the-convention-in-brief.html> accessed 10 January 2021.

20 'World Down Syndrome Day' (Down Syndrome International) <https://www.dsint.org/world-down-syndrome-day> accessed 1 January 2022.

21 ibid.

22 ibid.

23 ibid. 
for the human rights and freedoms of their citizens with a disability. However, as it is the case for several international pieces of legislation, the CRPD has more of a declarative function than it is an enforceable document for parties to use in a court setting. For this reason, more should be done to incorporate the CRPD principles into the legislation both at a federal and at a state level.

Although the U.S. has only signed CRPD and has yet to ratify it, the Convention holds a significant persuasive authority. While some scholars argue that since the U.S. did not ratify it, the CRPD is 'soft law' (a quasi-legal instrument), others argue that signature suffices to make the Convention 'hard law,' hence binding. ${ }^{24}$ Regardless, the CRPD is serving as a benchmark for the international community to abide by. ${ }^{25}$ The U.S. showed receptiveness to the CRPD when it amended the ADA to reflect its principles. For instance, by broadening the definition of what is a protectable disability under the law, and by valuing independence and fostering the principle of reasonable accommodation. ${ }^{26}$ However, there is more to be done to encourage countries like the United States to ratify the Convention and implement its principles. This would help in provoking a change in perception to improve the situation of persons with disabilities such as Down syndrome, in accordance with article 8 of the Convention. ${ }^{27}$

\subsection{The Americans with Disabilities Act (ADA) and Down Syndrome}

The Americans with Disabilities Act (ADA) was signed into law in the USA, on July $26,1990 . .^{28}$ The ADA is a comprehensive piece of civil rights legislation that prohibits discrimination against individuals with disabilities in several areas of public life, such as employment, education, transportation, telecommunication, and access to state and federal programs and services. ${ }^{29}$ The purpose of the law is to grant that people with disabilities have the same rights

24 'The United Nations Convention on the Rights of Persons with Disabilities: Issues in the U.S. Ratification Debate' <https://www.everycrsreport.com/reports/R42749.html> accessed 1 January 2022.

25 'Where the United States Stands on 10 International Human Rights Treaties' (n 16).

26 ibid.

27 'Convention on the Rights of Persons with Disabilities - Articles I United Nations Enable' <https://www.un.org/development/desa/disabilities/convention-on-the-rights-ofpersons-with-disabilities/convention-on-the-rights-of-persons-with-disabilities-2.html> accessed 1 January 2022.

28 'What Is the Americans with Disabilities Act (ADA)? I ADA National Network' $<$ https://adata.org/learn-about-ada> accessed 1 January 2022.

29 'Americans with Disabilities Act I U.S. Department of Labor'

<https://www.dol.gov/general/topic/disability/ada> accessed 1 January 2022. 
and opportunities as the general population. ${ }^{30}$ The ADA is divided into five titles that address different areas of public life. ${ }^{31}$

The ADA was amended in 2008, through the Americans with Disabilities Act Amendments Act (ADAAA), which became effective on January 1, 2009.32 Notably, the ADAAA amended the definition of 'disability' to clarify the term's scope better. As a result, the term 'disability' was more broadly defined to counteract case law that had been eroding and restricting the definition over the years. ${ }^{33}$ Further, the amendment moved the focus from a legalistic and formal approach to a more factual one that seeks to determine whether discrimination took place. ${ }^{34}$

\subsubsection{The Americans with Disabilities Act: Steps Ahead}

The ADA and the ADAAA enhanced the situation of people with disabilities in the United States. However, there is still room for improvement. More can be done to ensure that everyone, especially those with Intellectual and Developmental Disabilities (IDD) like Down syndrome, can learn, work, and be an active part of their community. This is because targeted educational programs, a stimulating environment at home and school, access to health care, and a sound support system are enabling components for people with a disability like Down syndrome to lead fulfilling and productive lives. Formally, people with Down syndrome can receive an education, work, participate in decisions that affect them, have meaningful relationships, vote, and contribute to society. ${ }^{35}$ However, this is not always the case, given the remaining barriers. Almost twice as many disabled Americans aged 16 and older live below the poverty level as people without disabilities. ${ }^{36}$ This may be attributable to various factors, including discrimination in the workplace and in accessing education and healthcare. However, the ADA

30 'What Is the Americans with Disabilities Act (ADA)? I ADA National Network' (n 28).

31 ibid.

32 ibid.

33 'An Employer View of the Changes from the ADA Amendments Act I ADA National

Network' <https://adata.org/factsheet/employer-view-ada> accessed 1 January 2022.

34 ibid.

35 ‘Down Syndrome Facts I National Down Syndrome Society' (NDSS)

$<$ https://www.ndss.org/about-down-syndrome/down-syndrome-facts/> accessed 1 January 2022.

36 'The Americans with Disabilities Act: A Civil Rights Landmark for People with Disabilities, Including Down Syndrome I Council on Contemporary Families' $<$ https://contemporaryfamilies.org/americans-with-disabilities-act/> accessed 1 January 2022. 
has provided grounds to challenge such discriminations judicially. The ADA allowed the rise of a new branch of lawyers who specialize in ADA complaints. ${ }^{37}$ Today, ADA claims are on the rise. ${ }^{38}$ This is attributable in part to the push coming from the international community, and in part to the changes brought about by the ADAAA, which encouraged advocacy for stricter enforcement of the ADA. ${ }^{39}$

\subsection{Disability Law in Italy: The Legge 104/1992}

The Legge 104/1992 (Legislative Act 104/1992) is the ADA's Italian equivalent. It provides a national legal framework to advance the interests of people with disabilities such as Down syndrome and to protect their rights. ${ }^{40}$ The Legge 104/1992, also known as 'Legge 104,' was adopted in 1992. Like the ADA in the U.S., it was subsequently amended to include the principles of the CRPD in 2010 and 2017. The Italian disability law framework under the Legge 104 focuses on providing access to services and assistance to individuals with a disability and promoting their rights and social integration. The Legge 104 seeks to achieve these goals by fostering welfare state policies that provide financial assistance, tax exemption programs, and work leave opportunities for families that have members with a disability such as Down syndrome. ${ }^{41}$

The Legge 104 was a turning point in the Italian disability legal framework. Specifically in regards to Down syndrome, to access the welfare state benefit, the individual needs to show proof of disability and its degree. ${ }^{42}$ Individuals with Down syndrome are automatically eligible to receive a monthly accompanying allowance of $522.10 €$ (equivalent to $\$ 593.70$ on 12/31/2021) (indennità di

\footnotetext{
37 'ADA Lawyers In Denver, Colorado I Baird Quinn LLC' (7 January 2021) $<$ https://www.bairdquinn.com/practice-areas/disability-discrimination/> accessed 1 January 2022.

38 'ADA Lawsuits on the Rise, 2019 Another Record-Breaking Year' (NJBIA - New Jersey Business \& Industry Association, 5 March 2020) <https://njbia.org/ada-lawsuits-on-the-rise2019-another-record-breaking-year/> accessed 31 December 2021. 39 'ADA Lawyers In Denver, Colorado I Baird Quinn LLC' (n 37).

${ }^{40}$ Legge 5 Febbraio 1992, N. 104, 'Gazzetta Ufficiale' $<$ https://www.gazzettaufficiale.it/eli/id/1992/02/17/092G0108/sg> accessed 1 January 2022. ${ }^{41}$ 'I diritti di chi soffre della sindrome Down' <https://www.laleggepertutti.it/164540_idiritti-di-chi-soffre-della-sindrome-down> (June 2017) accessed 1 January 2022.

${ }_{42}$ 'Messaggio Numero 28110 Del 09-11-2010' $<$ https://www.inps.it/Messaggi/Messaggio\%20numero\%2028110\%20del\%2009-112010.htm> accessed 1 January 2022.
} 
accompagnamento). ${ }^{43}$ People with Down syndrome are also eligible to be exempted from any medical and therapeutic expenses they incur. ${ }^{44}$ This comprises life-saving treatments, and also those treatments such as speech therapy and physiotherapy that are conducive to and enhance the quality of life and wellbeing of the individual. Further, minors are eligible for an additional monthly allowance of $287,09 €$ (equivalent to $\$ 326.46$ on $12 / 31 / 2021$ ) per month to cover their therapeutic and educational expenses (indennità di frequenza). ${ }^{45}$ Adults have access to a stipend of $287,09 €$ (equivalent to $\$ 326.46$ on $12 / 31 / 2021$ ) per month (pensione di invalidità) if their yearly income is lower than $16.982,49 €$ (equivalent to $\$ 19,311.56$ on $12 / 31 / 2021)$.

The text of the Legge 104 shows there is still a long road ahead to fight the stigma of disability in Italy. The text uses language that refers to people with a disability as "handicapped people," putting them in a category where the focus is on the disability, not on the individual, suggesting that their disability necessarily defines their identity. ${ }^{46}$ However, there are positive signs of change, as the new legislation and policies appear to be more attentive to the way language is used, to stress the person's centrality, rather than their disability. ${ }^{47}$

In 2020, the Italian Government published a dossier under the heading Iniziative per il rilancio Italia 2020-2022, aiming at establishing a policy plan of action to promote further an environment of integration for people with a disability such as Down syndrome in Italy. The dossier is groundbreaking because it is the first time Italy puts people with a disability at the forefront of a national policy strategy..$^{48}$ The dossier is even more revolutionary when putting it in the context of the COVID-19 pandemic, as it highlights that despite the challenging times we are

\footnotetext{
${ }^{43}$ ‘Circolare Numero 148 Del 18-12-2020.Pdf'

$<$ https://www.inps.it/CircolariZIP/Circolare\%20numero\%20148\%20del\%2018-12-

2020.pdf $>$ accessed 1 January 2022.

${ }_{44}$ 'I diritti di chi soffre della sindrome Down' (n 41).

45 ‘Gazzetta Ufficiale' <https://www.gazzettaufficiale.it/eli/id/2020/10/13/20A05541/sg> accessed 1 January 2022. Rinnovo 2021: Tabelle, IstiTUTO NAZIONALE DELLA PREVIDENZA SOCIALE (INPS) https://www.aipd.it/site/wp-content/uploads/2020/12/INPSCircolare1482020Allegato2.pdf (last visited 1 Jan. 2022).

${ }^{46}$ 'Legge 104 Del 5 Febbraio 1992: Il Testo' <https://www.studiocataldi.it/normativa/testolegge-104.asp> accessed 1 January 2022.

${ }^{47}$ See: Iniziativa per il Rilancio 'Italia 2020-2022': Rapporto per il Presidente del Ministri,

COMITATO Di ESPERTI IN MATERIA ECONOMICA E SOCIALE, available at http://www.governo.it/sites/new.governo.it/files/comitato rapporto.pdf. ${ }^{48} \mathrm{Id}$.
} 
facing worldwide, people with a disability are considered a priority by the Italian Government.

\section{Conception to Delivery and Pregnancy Termination: A Contested Legal Issue}

There is a contested legal issue before children with Down syndrome are born. In section 2.1, I explored the numbers and statistics concerning Down syndrome incidence in the U.S. and Europe. Many countries have laws and ongoing legal debates concerning these individuals before they are born, as is the case in the U.S. and Italy. Still, differences in law, policy, and culture significantly shape the conversation. The U.S. and Europe have similar incidence of Down syndrome, approximately 1 in 633; however, it is noted that the numbers vary significantly from region to region--for instance, in Italy, the estimate is that one every 1,200 children are born with Down syndrome. ${ }^{49}$ In contrast, according to the Ohio Department of Health, in Ohio, one in every 700 children are born with Down syndrome. ${ }^{50}$

\subsection{Reproductive Rights in The United States}

In the United States, the case Roe v. Wade (1973) determined that the Fourteenth Amendment's right of personal privacy includes a woman's right to choose to terminate a pregnancy. ${ }^{51}$ In Roe v. Wade, the Court ruled that a Texas law that prohibited all abortions except for life-saving abortions was unconstitutional. The Supreme Court held that the decision to terminate a pregnancy falls within the Constitutional right to privacy and is therefore fundamental. ${ }^{52}$ Further, the Court decided that a state could not interfere with the abortion decision unless the state possessed a compelling reason for regulating this conduct. Nevertheless, "with respect to the state's important and legitimate interest in potential life, the 'compelling' point is at viability." 53 Viability is usually after 24 weeks gestation, because "the fetus then presumably has the capability of meaningful life outside the mother's womb." ${ }^{54}$ Even after that, a state may allow abortion when necessary to

${ }_{49}$ ‘Sindrome Di Down: Colpisce Un Nato Ogni 1.200, Ma Non Esistono Statistiche Certe Quotidiano Sanità' <http://www.quotidianosanita.it/scienza-e-

farmaci/articolo.php?approfondimento_id=10731> accessed 1 January 2022.

50 ‘House Bill 214 I The Ohio Legislature'

$<$ https://www.legislature.ohio.gov/legislation/legislation-summary?id=GA132-HB-214> accessed 1 January 2022.

${ }^{51}$ Roe v. Wade, 410 US 113, 114 (1973).

${ }^{52} \mathrm{Id}$.

${ }^{53} \mathrm{Id}$.

${ }^{54}$ Roe v Wade, 410 US 113, 114 (1973). 
protect the mother's life or health. ${ }^{55}$ However, states have been challenging this paradigm, with impacting and limiting the choices available to expectant mothers if the fetus has Down syndrome. The most notable cases are those of the state of Ohio, Texas, and Mississippi.

\subsubsection{Ohio: The Ohio House Bill 214}

Many U.S. states, including Ohio, have found it challenging to balance a woman's privacy interests with the state's interests both in the woman's health and in the fetal life, while simultaneously honoring the duties of the medical profession. ${ }^{56}$

In 2017, Ohio legislators introduced the Ohio House Bill 214 (HB 214), which sought to amend sections of the Ohio Revised Code "to prohibit a person from performing, inducing, or attempting to perform or induce an abortion on a pregnant woman who is seeking the abortion because an unborn child has or may have Down syndrome." ${ }^{57}$ Later in 2017, the Ohio representatives passed the Bill in the Ohio House and, shortly thereafter, in the Ohio Senate. No other U.S. state has a ban in place that explicitly targets Down syndrome termination of pregnancies. ${ }^{58}$ Governor John Kasich signed the Bill into law in December 2017, and HB 214 became effective in March 2018. Nonetheless, a health clinic in Cleveland (PretermCleveland) sued challenging the constitutionality of the law and asking for an injunction to prevent it from becoming effective. ${ }^{59}$ The decision's oral argument was discussed in March 2020. In April 2021, after a significant delay due to the COVID-19 pandemic, a federal appeals court ruled that Ohio can enforce the 2017 law banning abortions when medical tests show that a fetus has Down syndrome. In a 9-7 decision, the 6th U.S. Circuit Court of Appeals in Cincinnati ruled that the law did not create a substantial obstacle to obtaining abortions, was reasonably related to Ohio's legitimate interests, and was "valid in all conceivable cases." 60

\footnotetext{
${ }^{55} \mathrm{Id}$.

${ }^{56}$ Kate L. Fetrow, Taking Abortion Rights Seriously: Toward a Holistic Undue Burden Jurisprudence, STANFORD LAW REVIEW, Jan. 2018, 70 STNLR 319, 321.

57 'House Bill 214 | The Ohio Legislature' (n 50).

${ }^{58}$ Rebecca B Reingold and Lawrence O Gostin, 'Banning Abortion in Cases of Down Syndrome: Important Lessons for Advances in Genetic Diagnosis' (2018) 319 JAMA 2375. ${ }^{59}$ Preterm-Cleveland v. Himes, 294 F. Supp. 3d 746 (S.D. Ohio 2018), aff'd, 940 F.3d 318 (6th Cir. 2019), reh'g en banc granted, opinion vacated, 944 F.3d 630 (6th Cir. 2019).

${ }^{60}$ Reuters and Jonathan Stempel, 'Ohio Can Enforce Ban on Down Syndrome Abortions U.S. Appeals Court' Reuters (13 April 2021) <https://www.reuters.com/world/us/ohio-canenforce-ban-down-syndrome-abortions-us-appeals-court-2021-04-13/> accessed 30
} 
The ruling lifts the injunction issued by a federal judge in March 2018 after Planned Parenthood and Preterm-Cleveland sued to challenge the Bill, and it de facto turns Ohio Bill 214 into a "don't ask, don't tell" law. ${ }^{61}$

Hence, under the current Ohio legislation, the most problematic aspects are, first, that a violation amounts to a fourth-degree felony. ${ }^{62}$ Second, any physicians who are found to have violated the law will have their license to practice medicine in Ohio revoked and will face extensive civil liability. Additionally, Down syndrome advocates are concerned that the Bill may be counterproductive to the efforts of destigmatizing Down syndrome, because the conversation would be a polarized one on abortion, rather than a productive debate on what it entails to raise a child with the syndrome. ${ }^{63}$

\subsubsection{Texas: Senate Bill 8}

Under the Trump Administration, the Supreme Court drastically changed in its composition. During his mandate, President Trump filled the Supreme Court vacancies with three new conservative-leaning justices: Brett Kavanaugh, Amy Coney Barrett, and Neil Gorsuch. ${ }^{64}$ With the swift change of Supreme Court make up under the Trump administration, there has been a new wave of anti-abortion bills across the United States; in an effort to overturn Roe v. Wade. ${ }^{65}$ These bills aim to shorten the window of time available to women to choose to terminate a pregnancy.

December 2021; Preterm-Cleveland et a v McCloud et al, 6th US Circuit Court of Appeals, No 18-3329.

61 'Divided Sixth Circuit Lets Ohio Ban Abortions Based on Down Syndrome Diagnosis' $<$ https://www.courthousenews.com/divided-sixth-circuit-lets-ohio-ban-abortions-basedon-down-syndrome-diagnosis/> accessed 30 December 2021.

${ }^{62}$ ABC News, 'US Court Lifts Hold on Ohio's Down Syndrome Abortion Law' (ABC News) $<$ https://abcnews.go.com/Health/wireStory/us-court-lifts-hold-ohios-syndrome-abortionlaw-77047821> accessed 31 December 2021.

${ }_{63}$ 'The Americans with Disabilities Act: A Civil Rights Landmark for People with

Disabilities, Including Down Syndrome I Council on Contemporary Families' (n 36).

${ }^{64}$ 'U.S. Senate: Supreme Court Nominations (1789-Present)'

$<$ https://www.senate.gov/legislative/nominations/SupremeCourtNominations1789presen t.htm> accessed 29 December 2021.

${ }^{65}$ Becky Sullivan, '21 States Poised to Ban or Severely Restrict Abortion If "Roe v. Wade" Is Overturned' NPR (2 December 2021)

$<$ https://www.npr.org/2021/12/02/1061015753/abortion-roe-v-wade-trigger-lawsmississippi-jacksons-womens-health-organization> accessed 29 December 2021. 
Most notably, the measures introduced in Texas stand out as particularly draconian and are amongst the most restrictive in the nation. ${ }^{66}$ As of September 1 , 2021, the state of Texas has enacted a new abortion restriction through the Senate Bill 8 ("SB 8") or "Heartbeat Bill." This law prevents providers from performing abortions in Texas beyond six weeks of pregnancy or when a fetal heartbeat is detected. ${ }^{67}$ This is consequential because Down syndrome is typically detected after 10 weeks of gestation with routine prenatal screening. ${ }^{68}$ The Law does not have exceptions for cases of rape and incest, or for genetic fetal abnormalities, including Down syndrome. ${ }^{69}$ The only exception created by SB 8 is in case of medical emergency, but the Bill is vague on what constitutes such emergency. ${ }^{70}$ Additionally, SB 8 is different from other abortion bans because it contains a private civil right of action, which is a legal provision that allows private individuals - not the state - to enforce the law. ${ }^{71}$ Further, this clause empowers anyone to sue an abortion provider as well as anyone else who assists a patient in obtaining abortion services and receive compensation of $\$ 10,000$ (equivalent to $8.793,95 €$ on $12 / 31 / 2021$ ), as well as legal fees covered. ${ }^{72}$

\subsubsection{Mississippi: The Gestational Age Act}

In 2018, the state of Mississippi, too, passed new anti-abortion legislation (known as the "Gestational Age Act") to restrict access to abortion beyond the $15^{\text {th }}$ week of pregnancy, except in case of a medical emergency. ${ }^{73}$ Even if fetal Down syndrome can be technically detected and confirmed by week 15 , this Act may still have the effect of limiting access to abortion because of logistical and health insurance-related considerations, especially amongst individuals with suboptimal prenatal care (which is present in approximately $20 \%$ of pregnancies in

${ }_{66}$ 'SB8' $8<$ https://www.plannedparenthood.org/planned-parenthood-gulf-coast/sb8> accessed 29 December 2021.

67 87(R) SB 8, 2021.

${ }^{68}$ Down syndrome - Diagnosis and treatment - Mayo Clinic, , https://www.mayoclinic.org/diseases-conditions/down-syndrome/diagnosistreatment/drc-20355983 (last visited Dec 29, 2021)

${ }_{69}$ Supra, 87(R) SB 8, 2021.

70 Supra, 87(R) SB 8, 2021.

${ }^{71} \mathrm{Id}$.

72 Id.

${ }^{73}$ Ariane de Vogue Reporter CNN Supreme Court, 'Supreme Court's Conservatives Lean towards Limiting Abortion Rights after Dramatic Oral Arguments on Mississippi Law Banning Abortions after 15 Weeks' (CNN) $<$ https://www.cnn.com/2021/12/01/politics/supreme-court-roe-v-wade-oralarguments/index.html> accessed 29 December 2021. 
Mississippi). ${ }^{74}$ Individuals with inadequate prenatal care are less likely to have access to non-invasive prenatal testing and hence the diagnosis of Down syndrome may be delayed to the anatomy ultrasound, which is performed at the 18-22 weeks or beyond. ${ }^{75}$ The Mississippi Gestational Age Act made headlines in December 2021, as the Supreme Court heard arguments of the case Dobbs v. Jackson Women's Health Organization, concerning the constitutionality of the Act. ${ }^{76}$ The final decision of the Court, which has the potential to overturn Roe $v$. Wade, is expected to come in the summer of $2022 .{ }^{77}$

\subsection{Italy: Law n. 194/1978}

In Italy, Law n. 194/1978 provides for the possibility of free abortion up to 12 weeks and six days of pregnancy. The only legal restriction is on the obligation to perform abortions in public hospitals. After this time, the determination to terminate a pregnancy when the fetus is malformed is based on the mother's physical or psychological health. ${ }^{78}$ Therefore, after the first twelve weeks of pregnancy, the focus shifts to the mother's health. In all cases, the termination of pregnancy must happen before viability (estimated around 23-24 weeks). The problem is that there is a vast policy difference between Italian regions, creating a non-homogenous and inconsistent legal and medical framework of operation. The matter falls into local administration competence.

The most problematic aspects under the Italian legislation are that if women are out of the 12 weeks and six-day period before they are aware of a fetal

74 'Prenatal Care Mississippi I PeriStats | March of Dimes'

$<$ https://www.marchofdimes.org/peristats/ViewTopic.aspx?reg=28\&top=5\&lev=0\&slev=4 $>$ accessed 30 December 2021.

${ }^{75}$ Meagan Smith and Jeannie Visootsak, 'Noninvasive Screening Tools for Down Syndrome: A Review' (2013) 5 International Journal of Women's Health 125; 'Fetal Ultrasound - Mayo Clinic' <https://www.mayoclinic.org/tests-procedures/fetalultrasound/about/pac-20394149> accessed 30 December 2021.

${ }^{76}$ Nina Totenberg, 'Roe v. Wade's Future Is in Doubt after Historic Arguments at Supreme Court' NPR (1 December 2021)

$<$ https://www.npr.org/2021/12/01/1060508566/roe-v-wade-arguments-abortion-supremecourt-case-mississippi-law $>$ accessed 30 December 2021.

'Dobbs v. Jackson Women's Health Organization - SCOTUSblog'

$<$ https://www.scotusblog.com/case-files/cases/dobbs-v-jackson-womens-health-

organization/> accessed 30 December 2021.

77 Id.

78 Special Report: Parental Screening Policies in Europe, EUROCAT (2010) available at https://www.orpha.net/actor/Orphanews/2010/doc/Special-Report-Prenatal-ScreeningPolicies.pdf. 
disease or malformation, it is unclear whether they can make an informed decision. This poses the issue that many women embark on a 'forum shopping' practice to terminate their pregnancy abroad.

However, in early 2021, the Corte di Cassazione (which is the highest court of appeal or court of last resort in Italy) shed some light on the matter. In the case Sentenza 27 ottobre 2020 - 15 gennaio 2021,n. 653, the Court decided that women can choose to interrupt a pregnancy beyond the $90^{\text {th }}$ day if there is a high probability of the presence of a pathology or fetal abnormality that can pose a serious concern for the physical and mental wellbeing of the woman. ${ }^{79}$ The determination is to be made case-by-case. ${ }^{80}$ The scope of the decision seems to encompass instances of Down syndrome, but more jurisprudence is needed for a more definitive answer on the matter. ${ }^{81}$

Then, a considerable obstacle to the safe and legal termination of pregnancy is represented by the fact that up to 70 percent of Italian OBGYN physicians are conscientious objectors. ${ }^{82}$ This problem is made worse because there is no national register that women can consult to identify a healthcare provider that would be willing to perform the abortion in a safe and regulated environment. ${ }^{83}$

Finally, there is a notable disagreement between regions (and in the literature) on what it is to be considered 'viability.' ${ }^{84}$ These factors have the effect of limiting access to safe and legal abortion, even when authorized by law.

\footnotetext{
79 Sentenza $n 653$ del 15/01/2021 (Corte di Cassazione).

80 'Interruzione di gravidanza: consentita anche dopo 90 giorni' (Altalex, 28 January 2021) $<$ https://www.altalex.com/documents/news/2021/01/28/interruzione-gravidanzaconsentita-anche-dopo-90-giorni> accessed 30 December 2021; 'Interruzione gravidanza oltre i 90 giorni, nuova sentenza della Cassazione. I Colletti\&Partners' (26 January 2021) $<$ https://www.collettiandpartners.it/2021/01/26/possibile-interruzione-oltre-i-90-giornipossibile-nuova-sentenza-della-cassazione/, https://www.collettiandpartners.it/2021/01/26/possibile-interruzione-oltre-i-90-giornipossibile-nuova-sentenza-della-cassazione/> accessed 30 December 2021.

81 'Interruzione di gravidanza: consentita anche dopo 90 giorni' (n 80); 'Interruzione gravidanza oltre i 90 giorni, nuova sentenza della Cassazione. I Colletti\&Partners' (n 80). 82 Francesca Minerva, Conscientious objection in Italy, 41 J Med ETHICs 170-173 (2015).

83 'Medici Obiettori, Trasparenza e Privacy Da Rivedere - Info Data' $<$ https://www.infodata.ilsole24ore.com/2017/07/05/medici-obiettori-trasparenza-privacyrivedere/?refresh_ce=1> accessed 1 January 2022.

${ }^{84}$ Anita Catlin, 'Fetus' in Henk ten Have (ed), Encyclopedia of Global Bioethics (Springer International Publishing 2016) <https://doi.org/10.1007/978-3-319-09483-0_196> accessed 31 December 2021; Elizabeth Chloe Romanis, 'Is "Viability" Viable? Abortion, Conceptual Confusion and the Law in England and Wales and the United States' (2020) 7 Journal of Law and the Biosciences lsaa059.
} 


\section{Early Childhood and Development}

The level of assistance to families with children with Down syndrome varies in Italy and the United States. However, much of the legislation in both countries is not specific to Down syndrome, but it falls under the legislative safeguards and benefits attributed to families whose family member has an intellectual or physical disability.

\subsection{The United States and Italy: Cost and Access to Care}

This section focuses primarily on the United States, as in Italy, healthcare is universal and guaranteed to all. ${ }^{85}$ Therefore, many of these considerations are particularly relevant in the United States, where healthcare, and its associated costs, are much more variable.

Studies drawing from the 2005-2006 National Survey of Children with Special Healthcare Needs (NSCSHN) dataset delineated Down syndrome's effects on families. Specifically, they highlighted that a stunning 60 percent of families of children with Down syndrome provide comprehensive healthcare (i.e., from giving medications and therapy to manage feeding and breathing equipment) at home. ${ }^{86}$ For this reason, almost half of these families had a family member stop working, and 40 percent of the families reported that their child's syndrome caused financial hardships and strain on the family. ${ }^{87}$ When it comes to healthcare, the average cost of medical care in children aged 0-4 with Down syndrome is 12 times the cost of an infant not born with Down syndrome. ${ }^{88}$ Moreover, it is relatively common for children with Down syndrome to be born with a heart defect, which multiplies by five times the already high costs associated with taking care of a child with Down syndrome in their first year of life. ${ }^{89}$

The high costs and financial hurdles that families of children with Down syndrome are remarkable and add a significant layer of stress on top of dealing with the ramifications of their child's diagnosis. This is particularly true for families that might already face disadvantage and marginalization. For instance,

${ }^{85}$ Lo Scalzo A, Donatini A, Orzella L, Cicchetti A, Profi li S, Maresso A, Italy: Health System Review, HEALTH SYSTEMS IN TRANSITION, 2009; 11(6)1-216.

${ }^{86}$ Laura A Schieve and others, 'A Population-Based Assessment of the Health, Functional Status, and Consequent Family Impact among Children with Down Syndrome' (2011) 4 Disability and Health Journal 68.

87 ibid.

88 Sheree L Boulet and others, 'Health Care Expenditures for Infants and Young Children with Down Syndrome in a Privately Insured Population' (2008) 153 The Journal of Pediatrics 241.

89 ibid. 
the research highlighted that African-American children with Down syndrome have a lower chance of surviving beyond the first year of life than white infants with Down syndrome. ${ }^{90}$

Given the high costs of care associated with Down syndrome, access to high-quality, affordable health insurance is crucial. While healthcare is guaranteed to all citizens in Italy, the U.S. has a combined public/private system that can leave some people behind, especially those who are most vulnerable. With the passage of the Affordable Care Act in 2010, the U.S. Federal Government opened the door for states to expand healthcare access through Medicaid Expansion..$^{91}$ This has improved access to healthcare for individuals with Down syndrome and their families in numerous ways. First, some children will be covered by state Medicaid due solely to their family income. ${ }^{22}$ Second, nearly all states have elected to expand Medicaid eligibility for children with special health care needs, such as Down syndrome. ${ }^{93}$

While these programs have improved access to care, there remain several key issues and barriers. Not all states elected to expand Medicaid coverage; twelve states have yet to do so. ${ }^{94}$ Ohio approved the Medicaid expansion in 2013. However, there are ongoing legal issues in the work requirement currently being planned for implementation in 2021 (though this requirement would not apply to those with disabilities). ${ }^{95}$ Furthermore, there have been ongoing political attempts

${ }^{90}$ James E Kucik and others, 'Trends in Survival among Children with Down Syndrome in 10 Regions of the United States' (2013) 131 Pediatrics e27.

91 'Read the Affordable Care Act, Health Care Law' (HealthCare.gov) $<$ https://www.healthcare.gov/where-can-i-read-the-affordable-care-act/> accessed 1 January 2022.

92 Priya Chidambaram Published: Jun 12 and 2019, 'Medicaid's Role for Children with Special Health Care Needs: A Look at Eligibility, Services, and Spending' (KFF, 12 June 2019) <https://www.kff.org/medicaid/issue-brief/medicaids-role-for-children-withspecial-health-care-needs-a-look-at-eligibility-services-and-spending/> accessed 1 January 2022.

93 ibid.

${ }^{94}$ Published: Nov 02 and 2020, 'Status of State Medicaid Expansion Decisions: Interactive Map' (KFF, 2 November 2020) <https://www.kff.org/medicaid/issue-brief/status-of-statemedicaid-expansion-decisions-interactive-map/> accessed 1 January 2022.

95 'Ohio and the ACA's Medicaid Expansion: Eligibility, Enrollment and Benefits' (healthinsurance.org, 5 October 2020) <https://www.healthinsurance.org/ohio-medicaid/> accessed 1 January 2022. 
at "repealing and replacing" the Affordable Care Act, meaning these pathways to health insurance may not be enduring. ${ }^{96}$

In 2014, the Achieving a Better Life Experience (ABLE) Act was passed, adding Section 529A to the federal tax code. ${ }^{97}$ This law provides people with disabilities and their families the ability to put money into a tax-exempt account that may be used for qualified disability expenses. ${ }^{98}$ Before this Bill, crucial benefits such as Medicaid and Supplement Security Income could be jeopardized if a disabled person had more than $\$ 2,000$ of savings in their name (equivalent to $1758,79 €$ on 12/31/2021). ${ }^{99}$ Now, people with disabilities and their families can contribute up to $\$ 15,000$ (equivalent to $13.190,79 €$ on $12 / 31 / 2021$ ) per year from their post-tax earnings without fear of losing benefits. ${ }^{100}$ This protects crucial benefits and empowers families to ensure ongoing access to care and resources. Given the high costs associated with healthcare in the U.S., this legislation can provide some much-needed relief. Though this legislation was a significant step forward in supporting people with disabilities, contributions must come from post-tax earnings, meaning this legislation may not benefit those who are financially disadvantaged.

\section{Conclusive Remarks: Proposals Going Forward}

The United States' disability law and policies are not uniform and vary significantly from state to state. The same is true within the European Union member states, where benefits and opportunities for families and individuals with Down syndrome differ significantly. Families of individuals with Down syndrome and the individuals themselves already face numerous challenges. These span from making sure the needs (i.e., medical, and therapeutic) of the person with a disability are attended, to worrying about the financial ramifications of taking care of such needs. It would be valuable if countries were to make an honest effort to harmonize law and policies and provide the tools to navigate them, even to nonsophisticated parties.

${ }_{96}$ Charley E Willison and Phillip M Singer, 'Repealing the Affordable Care Act Essential Health Benefits: Threats and Obstacles' (2017) 107 American Journal of Public Health 1225. ${ }^{97}$ Ander Crenshaw, 'H.R.647 - 113th Congress (2013-2014): ABLE Act of 2014' (2 January 2015) <https://www.congress.gov/bill/113th-congress/house-bill/647> accessed 1 January 2022.

98 ibid.

${ }_{99}$ A Promising Future Together: A Guide for New and Expectant Parents, NATIONAL Down SYNDROME SOCIETY, Available at https://www.ndss.org/wpcontent/uploads/2020/06/NEPG v14.pdf. ${ }_{100}$ Crenshaw (n 97). 
In the United States, healthcare is mostly privatized, and there is no universal healthcare. This poses enormous barriers for families to financially navigate the system in order to attend the needs of their family member with Down syndrome. Efforts should be made to provide accessible guides on where to apply for programs and how to qualify for funding.

In Italy, there is universal healthcare. The most significant issue presently is to facilitate engagement with the national healthcare system so that families and individuals alike are afforded the chance to utilize all the opportunities available. While many programs support families of individuals with Down syndrome, they are not organically organized and accessible. Therefore, families risk missing out on precious therapeutic opportunities.

On the topic of termination of pregnancy in the U.S., and specifically in Ohio, further clarity is needed on the opportunities available to parents who are facing this difficult decision. While informed consent needs to be put at the forefront, balancing the interests of a fetus with Down syndrome and the mother's well-being is a delicate task. In Ohio, the April 2021 decision in the Preterm Case significantly restricted the options available to women expecting a child with Down syndrome, de facto turning Ohio Bill 214 into a "don't ask, don't tell law," with potential devastating consequences for families and medical practitioners alike if they are found to be in violation of the law.

With the swift change of Supreme Court make up under the Trump administration, there has been a new wave of anti-abortion bills across the United States in an attempt to overturn Roe v. Wade. ${ }^{101}$ These bills aim to shorten the window of time available to women to choose to terminate a pregnancy. Notably, the measures introduced in Texas through Senate Bill 8 ("SB 8") stand out as particularly draconian because they prevent providers from performing abortions in Texas beyond six weeks of pregnancy or when a fetal heartbeat is detected. ${ }^{102}$ This is consequential because Down syndrome is typically detected after 10 weeks of gestation with routine prenatal screening. ${ }^{103}$ A problematic aspect of the law is that it sets out a questionable "bounty" system where individual citizens are encouraged to sue those who, for any reason, decide to terminate a pregnancy after the six week timeframe.

101 Sullivan (n 65).

102 87(R) SB 8, 2021.

${ }^{103}$ Down syndrome - Diagnosis and treatment - Mayo Clinic, , https://www.mayoclinic.org/diseases-conditions/down-syndrome/diagnosistreatment/drc-20355983 (last visited Dec 29, 2021) 
Similarly, the Gestational Age Act in Mississippi restricts access to abortion beyond the $15^{\text {th }}$ week of pregnancy, with no exceptions other than a medical emergency. This disproportionately affects families with low socioeconomic status, which often accompanies reduced access to healthcare. Therefore, it exposes vulnerable populations to the risk of not being able to grant a dignified life to a child born with congenital issues like Down syndrome.

In Italy, the most significant concern is that while the state grants the right to women to make an informed decision to terminate their pregnancy if the fetus has Down syndrome, there is a large number of conscientious objectors. Therefore, this right is often de facto negated. A step forward would be to create a national database or registry to track those conscientious objectors. However, this raises potential privacy concerns, which adds an extra challenge to pursuing this endeavor.

Rather than relying on the parents' socio-economic status, the forefront of the discussion should be to build a support framework for parents who have children with Down syndrome. On this note, law and policy regarding access to care make a significant difference in the quality of life of children with Down syndrome. This may contribute to families feeling encouraged and confident that they are able to take care of a child with Down syndrome. In turn, there are reasons to believe this might also contribute to lowering the rates of termination of pregnancies where the fetus is diagnosed with a disability.

There is still advocacy work to be done to advance the rights of individuals with Down syndrome. Down syndrome is a commonly occurring chromosomal abnormality. Every day, progress in medicine and therapy helps individuals with Down syndrome live with an improving quantity and quality of life. However, the stigma is still very much present, and the perception is that individuals with Down syndrome are not openly accepted by society. ${ }^{104}$ Greater involvement of these people with Down syndrome in society or advocacy that improves public awareness are venues to fight back the stigma and improve social attitudes towards Down syndrome.

Recently, social media have provided a platform to counteract the stigma. An increasing number of individuals with Down syndrome or with loved ones living with the syndrome have started their own YouTube channel, Instagram,

104 Renu Jain, David C Thomasma and Rasa Ragas, 'Down Syndrome: Still a Social Stigma' (2002) 19 American Journal of Perinatology 099. 
TikTok, or Twitter account where they help raise awareness on the disability. ${ }^{105}$ Many of these channels have a large following and, therefore, the potential to influence the perspective of many. A change in perception is crucial to improve the situation of individuals with Down syndrome and to counteract the stigma and stereotypes of their capabilities. ${ }^{106}$ However, social media have also provided yet another platform for discriminatory behaviors, and more work needs to be done to counteract bullying and misinformation in the cyberspace.

The Americans with Disabilities Act (ADA) in the U.S., the Legge 104/1992 in Italy, and the Convention on the Rights of Persons with Disabilities (CRPD) internationally highlight how there is a push towards pursuing a person-centered care approach to acknowledge each person's unique story and autonomy to make self-directed decisions. A person-centered approach should be paired with a relationship-centered care approach, one that values the importance of the connections that individuals with a disability develop during their personal and professional life. Only by focusing on the individual as an active subject, we will embody the holistic and humanistic ideals that our society set to pursue to fully integrate individuals with disabilities like Down syndrome in our communities and acknowledge the value they bring to it.

105 See on YouTube.com: 'Raising Autumn'; 'The Ups and Downs'; several episodes on 'Truly'; 'This Extra Gift.' Instagram.com: 'thehouseofwheeler'; 'extraevielove.' 106 'Convention on the Rights of Persons with Disabilities - Articles I United Nations Enable' (n 27). 


\section{Bibliography}

'ADA Lawsuits on the Rise, 2019 Another Record-Breaking Year' (NJBIA - New Jersey Business $\mathcal{E}$ Industry Association, 5 March 2020) <https://njbia.org/adalawsuits-on-the-rise-2019-another-record-breaking-year/> accessed 31 December 2021

'ADA Lawyers In Denver, Colorado I Baird Quinn LLC' (7 January 2021) $<$ https://www.bairdquinn.com/practice-areas/disability-discrimination/> accessed 1 January 2022

'Americans with Disabilities Act I U.S. Department of Labor' <https://www.dol.gov/general/topic/disability/ada> accessed 1 January 2022

'An Employer View of the Changes from the ADA Amendments Act I ADA National Network' <https://adata.org/factsheet/employer-view-ada> accessed 1 January 2022

Boulet SL and others, 'Health Care Expenditures for Infants and Young Children with Down Syndrome in a Privately Insured Population' (2008) 153 The Journal of Pediatrics 241

Catlin A, 'Fetus' in Henk ten Have (ed), Encyclopedia of Global Bioethics (Springer International Publishing 2016) <https://doi.org/10.1007/978-3-319-09483-0_196> accessed 31 December 2021

CATTANEO B, 'Down Syndrome in Europe - Has the Disorder Epidemiology Changed over the Last Quarter-Century?' (EU Science Hub - European Commission, 21 March 2019) <https://ec.europa.eu/jrc/en/news/down-syndrome-europe-hasdisorder-epidemiology-changed-over-last-quarter-century $>$ accessed 1 January 2022

CDC, 'Data and Statistics on Down Syndrome I CDC' (Centers for Disease Control and Prevention, 4 December 2019)

$<$ https://www.cdc.gov/ncbddd/birthdefects/downsyndrome/data.html> accessed 1 January 2022

'Circolare Numero 148 Del 18-12-2020.Pdf'

<https://www.inps.it/CircolariZIP/Circolare\%20numero\%20148\%20del\%2018-122020.pdf $>$ accessed 1 January 2022

'Convention on the Rights of Persons with Disabilities - Articles I United Nations Enable' <https://www.un.org/development/desa/disabilities/convention-on-the- 
FRANCESCA GOTTARDI, ESQ., Down Syndrome Legislation in the U.S. and in Italy

rights-of-persons-with-disabilities/convention-on-the-rights-of-persons-withdisabilities-2.html> accessed 1 January 2022

'Convention on the Rights of Persons with Disabilities (CRPD) I United Nations Enable' $<$ https://www.un.org/development/desa/disabilities/convention-on-therights-of-persons-with-disabilities.html> accessed 1 January 2022

Crenshaw A, 'H.R.647 - 113th Congress (2013-2014): ABLE Act of 2014' (2 January 2015) <https://www.congress.gov/bill/113th-congress/house-bill/647> accessed 1 January 2022

'Divided Sixth Circuit Lets Ohio Ban Abortions Based on Down Syndrome Diagnosis' <https://www.courthousenews.com/divided-sixth-circuit-lets-ohioban-abortions-based-on-down-syndrome-diagnosis/> accessed 30 December 2021

'Dobbs v. Jackson Women's Health Organization - SCOTUSblog' $<$ https://www.scotusblog.com/case-files/cases/dobbs-v-jackson-womens-healthorganization/> accessed 30 December 2021

'Down Syndrome - Symptoms and Causes' (Mayo Clinic) $<$ https://www.mayoclinic.org/diseases-conditions/down-syndrome/symptomscauses/syc-20355977> accessed 1 January 2022

'Down Syndrome Facts I National Down Syndrome Society' (NDSS) $<$ https://www.ndss.org/about-down-syndrome/down-syndrome-facts/> accessed 1 January 2022

'Fetal Ultrasound - Mayo Clinic' <https://www.mayoclinic.org/testsprocedures/fetal-ultrasound/about/pac-20394149> accessed 30 December 2021

'Gazzetta Ufficiale' <https://www.gazzettaufficiale.it/eli/id/1992/02/17/092G0108/sg> accessed 1 January 2022

'- - ' <https://www.gazzettaufficiale.it/eli/id/2020/10/13/20A05541/sg> accessed 1 January 2022

'House Bill 214 I The Ohio Legislature' $<$ https://www.legislature.ohio.gov/legislation/legislation-summary?id=GA132HB-214> accessed 1 January 2022

'I diritti di chi soffre della sindrome Down' $<$ https://www.laleggepertutti.it/164540_i-diritti-di-chi-soffre-della-sindromedown> accessed 1 January 2022 
'Interruzione di gravidanza: consentita anche dopo 90 giorni' (Altalex, 28 January 2021) <https://www.altalex.com/documents/news/2021/01/28/interruzionegravidanza-consentita-anche-dopo-90-giorni> accessed 30 December 2021

'Interruzione gravidanza oltre i 90 giorni, nuova sentenza della Cassazione. I Colletti\&Partners' (26 January 2021) $<$ https://www.collettiandpartners.it/2021/01/26/possibile-interruzione-oltre-i-90giorni-possibile-nuova-sentenza-della-cassazione/, https://www.collettiand partners.it/2021/01/26/possibile-interruzione-oltre-i-90giorni-possibile-nuova-sentenza-della-cassazione/> accessed 30 December 2021

Jain R, Thomasma DC and Ragas R, 'Down Syndrome: Still a Social Stigma' (2002) 19 American Journal of Perinatology 099

Jun 12 PCP and 2019, 'Medicaid's Role for Children with Special Health Care Needs: A Look at Eligibility, Services, and Spending' (KFF, 12 June 2019) $<$ https://www.kff.org/medicaid/issue-brief/medicaids-role-for-children-withspecial-health-care-needs-a-look-at-eligibility-services-and-spending/> accessed 1 January 2022

Kucik JE and others, 'Trends in Survival among Children with Down Syndrome in 10 Regions of the United States' (2013) 131 Pediatrics e27

'Legge 104 Del 5 Febbraio 1992: Il Testo'

$<$ https://www.studiocataldi.it/normativa/testo-legge-104.asp > accessed 1 January 2022

'Medici Obiettori, Trasparenza e Privacy Da Rivedere - Info Data' $<$ https://www.infodata.ilsole24ore.com/2017/07/05/medici-obiettori-trasparenzaprivacy-rivedere/?refresh_ce=1 $>$ accessed 1 January 2022

'Messaggio Numero 28110 Del 09-11-2010' $<$ https://www.inps.it/Messaggi/Messaggio\%20numero\%2028110\%20del\%200911-2010.htm> accessed 1 January 2022

'NDSS-Preferred-Language-Guide-2020-2.Pdf' <https://www.ndss.org/wpcontent/uploads/2020/11/NDSS-Preferred-Language-Guide-2020-2.pdf $>$ accessed 1 January 2022

News ABC, 'US Court Lifts Hold on Ohio's Down Syndrome Abortion Law' (ABC News) <https://abcnews.go.com/Health/wireStory/us-court-lifts-hold-ohiossyndrome-abortion-law-77047821> accessed 31 December 2021 
Nov 02 P and 2020, 'Status of State Medicaid Expansion Decisions: Interactive Map' (KFF, 2 November 2020) <https://www.kff.org/medicaid/issue-brief/statusof-state-medicaid-expansion-decisions-interactive-map/> accessed 1 January 2022

'Ohio and the ACA's Medicaid Expansion: Eligibility, Enrollment and Benefits' (healthinsurance.org, 5 October 2020) <https://www.healthinsurance.org/ohiomedicaid/> accessed 1 January 2022

'Prenatal Care Mississippi I PeriStats I March of Dimes' $<$ https://www.marchofdimes.org/peristats/ViewTopic.aspx?reg=28\&top=5\&lev=0 \&slev $=4>$ accessed 30 December 2021

'Principles for the Protection of Persons with Mental Illness and the Improvement of Mental Health Care' <http://digitallibrary.un.org/record/162032> accessed 1 January 2022

'Read the Affordable Care Act, Health Care Law' (HealthCare.gov) $<$ https://www.healthcare.gov/where-can-i-read-the-affordable-care-act/> accessed 1 January 2022

Reingold RB and Gostin LO, 'Banning Abortion in Cases of Down Syndrome: Important Lessons for Advances in Genetic Diagnosis' (2018) 319 JAMA 2375

Reporter A de V CNN Supreme Court, 'Supreme Court's Conservatives Lean towards Limiting Abortion Rights after Dramatic Oral Arguments on Mississippi Law Banning Abortions after 15 Weeks' (CNN) $<$ https://www.cnn.com/2021/12/01/politics/supreme-court-roe-v-wade-oralarguments/index.html> accessed 29 December 2021

Reuters and Stempel J, ‘Ohio Can Enforce Ban on Down Syndrome Abortions U.S. Appeals Court' Reuters (13 April 2021) $<$ https://www.reuters.com/world/us/ohio-can-enforce-ban-down-syndromeabortions-us-appeals-court-2021-04-13/> accessed 30 December 2021

Romanis EC, 'Is "Viability" Viable? Abortion, Conceptual Confusion and the Law in England and Wales and the United States' (2020) 7 Journal of Law and the Biosciences lsaa059

'SB8' <https://www.plannedparenthood.org/planned-parenthood-gulf-coast/sb8> accessed 29 December 2021

Schieve LA and others, 'A Population-Based Assessment of the Health, Functional Status, and Consequent Family Impact among Children with Down Syndrome' (2011) 4 Disability and Health Journal 68 
'Sindrome Di Down: Colpisce Un Nato Ogni 1.200, Ma Non Esistono Statistiche Certe - Quotidiano Sanità' <http://www.quotidianosanita.it/scienza-efarmaci/articolo.php?approfondimento_id=10731> accessed 1 January 2022

Smith M and Visootsak J, 'Noninvasive Screening Tools for Down Syndrome: A Review' (2013) 5 International Journal of Women's Health 125

Sullivan B, '21 States Poised to Ban or Severely Restrict Abortion If “Roe v. Wade" Is Overturned' NPR (2 December 2021) $<$ https://www.npr.org/2021/12/02/1061015753/abortion-roe-v-wade-trigger-lawsmississippi-jacksons-womens-health-organization> accessed 29 December 2021

'The Americans with Disabilities Act: A Civil Rights Landmark for People with Disabilities, Including Down Syndrome I Council on Contemporary Families' $<$ https://contemporaryfamilies.org/americans-with-disabilities-act/> accessed 1 January 2022

'The Convention in Brief I United Nations Enable' $<$ https://www.un.org/development/desa/disabilities/convention-on-the-rights-ofpersons-with-disabilities/the-convention-in-brief.html> accessed 1 January 2022

'The United Nations Convention on the Rights of Persons with Disabilities: Issues in the U.S. Ratification Debate' $<$ https://www.everycrsreport.com/reports/R42749.html> accessed 1 January 2022

Totenberg N, 'Roe v. Wade's Future Is in Doubt after Historic Arguments at Supreme Court' NPR (1 December 2021) <https://www.npr.org/2021/12/01/1060508566/roe-v-wade-arguments-abortionsupreme-court-case-mississippi-law > accessed 30 December 2021

'United Nations Treaty Collection' $<$ https://treaties.un.org/pages/ViewDetails.aspx?src=TREATY\&mtdsg_no=IV$15 \&$ chapter $=4>$ accessed 1 January 2022

'U.S. Senate: Supreme Court Nominations (1789-Present)' $<$ https://www.senate.gov/legislative/nominations/SupremeCourtNominations178 9present.htm> accessed 29 December 2021

'What Is the Americans with Disabilities Act (ADA)? I ADA National Network' $<$ https://adata.org/learn-about-ada> accessed 1 January 2022

'Where the United States Stands on 10 International Human Rights Treaties' (The Leadership Conference Education Fund) $<$ https://civilrights.org/edfund/resource/where-the-united-states-stands-on-10international-human-rights-treaties/> accessed 1 January 2022 
FRANCESCA GOTTARDI, ESQ., Down Syndrome Legislation in the U.S. and in Italy

Willison CE and Singer PM, 'Repealing the Affordable Care Act Essential Health Benefits: Threats and Obstacles' (2017) 107 American Journal of Public Health 1225

'World Down Syndrome Day' (Down Syndrome International) <https://www.dsint.org/world-down-syndrome-day> accessed 1 January 2022

Preterm-Cleveland et a v McCloud et al, 6th US Circuit Court of Appeals, No 18-3329

Roe v Wade, 410 US 113, 114 (1973)

Sentenza $n 653$ del 15/01/2021 (Corte di Cassazione) 